\title{
Production of valuable oak wood in Europe
}

\author{
Heinrich Spiecker ${ }^{\circledR}$
}

Spiecker H., 2021. Production of valuable oak wood in Europe. Ann. For. Res. 64(1): 5-12.

\begin{abstract}
Large dimension branch free wood of pedunculate oak (Quercus robur L.) and sessile oak (Q. petraea (Matt.) Liebl.) is highly valued, while small sized and low-quality oak timber generate little income. This paper describes how large dimensions of branch free wood can be produced by applying appropriate silvicultural measures. The results are based on measurements of oak trees in various regions in Germany and Denmark. Two management phases are distinguished: In phase 1 pruning is emphasized and at the beginning of phase 2 future crop trees are selected to promote diameter growth of these oak trees. The resulting guidelines provide a quantitative basis for objective-oriented oak management.
\end{abstract}

Keywords: valuable wood, oak management, spacing, crown expansion, diameter growth, pruning, thinning.

Addresses: ${ }^{1}$ Albert-Ludwigs-University, Freiburg, Germany.

$\varpi$ Corresponding Author: Heinrich Spiecker (instww@uni-freiburg.de).

Manuscript received April 5, 2021; revised May 28, 2021; accepted June 25, 2021.

\section{Introduction}

Oaks are found in a wide range of forests worldwide (FAO 2006). In Europe, two oak species are relevant for valuable wood production: pedunculate oak (Quercus robur L.) and sessile oak (Q. petraea (Matt.) Liebl.). The natural range of pedunculate oak extends from Finland to Sicily and from Portugal to the Caspian Sea (Jahn 1991), while the natural range of sessile oak is considerably smaller, being restricted to sites where the climate is influenced by maritime conditions (BaryLenger et al. 1993). Today's distribution of oak is strongly influenced by human interventions. Both oaks are known to be light demanding as well as sensitive to frost (Evans 1984). However, oaks are quite resilient to the detrimental effects of flooding, especially in the case of pedunculate oak, storm damage, drought and they are extremely long lived. Although sessile oak can be found on dry sites, high valued sessile oak is generally found on sites with higher water availability over a wide range of soil $\mathrm{pH}$-values. In oak/beech mixed forests, these oaks can compete only in the early phases of stand development whereupon in later stages beech often suppresses the oak. In these mixed forests, the vitality of oak can be maintained only through selective thinning favoring oak trees (Eaton et al. 2016, Maleki et al. 2020).

Because oak is appreciated by forest owners and environmentalists alike, oaks are promoted through intensive management. In France, $30 \%$ of the forest area consists of oaks (Timbal \& Aussenac 1996), in Ukraine 25\% (Lavnyy \& Spiecker 2015), in Romania 18\% (Oprea et al. 2018) and in Germany 10\% (Lavnyy \& Spiecker 2015). The cost of establishing oaks is 
high compared to other species, including cost for planting, weed control, protection against browsing and early tending. In addition, the total growing cycle for producing valuable saw logs and veneer logs is extremely long. These economic disadvantages are compensated for by the high price of the valuable oak timber.

While small sized and low-quality oak timber generate little income, branch free wood of straight, large dimension oak timber, in contrast, is highly valued. The relevant characteristics of valuable oak wood are large dimension, branch free wood, stem form (taper, spiral grain), straightness, little eccentricity and ovality, no mechanical damage, light colour and fine wood structure. This paper describes how large dimensions of branch free wood can be produced by applying appropriate silvicultural measures in forest stands where oak is present.

\section{Materials and Methods}

The data used to formulate silvicultural recommendations contained in this paper come from 41 research plots, each consisting of 25 oak trees in even aged oak stands in Germany and Denmark. The two selection criteria for the sites were (1) sites typically dominated by oak and (2) wide range of different treatments. The sites are situated at an elevation of 50 to $650 \mathrm{~m}$, the average annual air temperature is $8-9{ }^{\circ} \mathrm{C}$ and the average annual precipitation is $600-800 \mathrm{~mm}$. The soil types are quite diverse, including for example Braun earth, Para brown earth, Terra fusca, Pseudogley, or Flood-plain soils.

Stand age varied from 40 to 120 years. Stand treatment varied considerably, basal area varied from 18 to $32 \mathrm{~m}^{2}$ per ha and relative crown length ranged from $70 \%$ in intensively thinned stands to $30 \%$ in densely grown stands.

Plot size was determined by the number of 25 oaks. Crown length, crown projection area, and the base of the lowest visible dead branch of these trees and the neighbouring trees outside the plot were measured for a total of 1300 oaks. The plot borders were delineated by a polygon between the crown areas at the plot border. In addition, tree age of all trees was determined and the diameter at $1.3 \mathrm{~m}$, total height and the height of the crown base were measured. Secondary shoots (epicormic branches) were classified by the height on the tree bole and the length of the shoot and counted for each oak within the plots. In a few cases trees were cut for analysing annual radial growth based on tree rings.

Pruning of oak branches is generally achieved through natural shedding. It is induced by competition of neighbouring trees. Branches of oak die soon after being shaded and the dead branches break off easily. An increased (higher) crown base is a good indicator for describing the pruning dynamics.

Crown size has a strong impact on diameter growth (Attocchi \& Skovsgaard 2015). By increasing growing space in a forest stand, the crown can expand and diameter growth can be accelerated. Modelling the relation between horizontal crown expansion and diameter growth provides a quantitative basis for controlling the diameter growth and allows for developing thinning intensity rules.

\section{Results}

\section{Pruning}

The relative height of the crown base can be modelled as a multiple linear regression, using the diameter at $1.3 \mathrm{~m}$ and the average annual radial increment as explaining variables. The analysis included 1300 trees $(n=1300)$.

Equation 1:

$$
\mathrm{h}_{\mathrm{c}}(\%)=86-0.24 \times \mathrm{d}_{1.3}-11.14 \times \mathrm{ir}_{1.3}
$$

where $h_{c}(\%)=$ relative height of the crown base, $\mathrm{d}_{1.3}=$ diameter at $1.3 \mathrm{~m}$ and ir $_{1.3}=$ average annual radial increment at $1.3 \mathrm{~m}$ height. 
Equation 1 shows that competition has a strong effect on natural pruning. Increasing competition reduces radial increment and, at the same time, increases the height of the crown base. It, as well, shows that large diameter trees show a lower relative crown base than small diameter trees.

Oak generally tends to produce secondary branches (called water sprouts or epicormic branches). However, individual trees behave differently. Epicormic branches get older and bigger towards the crown. Therefore, the negative impact on wood quality increases with the stem height. Crown development has little effect on the number of epicormic branches, but a strong impact on their size and vitality. Trees with small crowns show older and larger epicormic branches, in general, while the growth and vitality of epicormic branches of dominant trees with large crowns are reduced and their mortality is high.

\section{Diameter growth}

The strong linear relation between crown width and tree diameter in even aged stands is shown in figure 1).

Crown width [m]

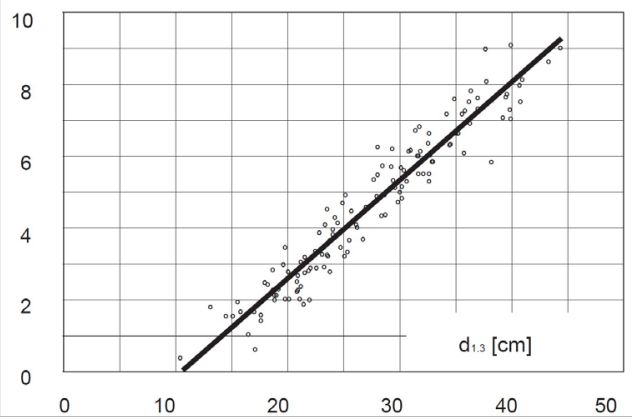

Figure 1 There is a strong linear relation between the diameter at $1.3 \mathrm{~m}$ height $\left(\mathrm{d}_{1,3}\right)$ and the crown width of oaks in a 56-yearold oak stand.

A multiple linear regression has been used for modelling the crown diameter as a function of $\mathrm{d}_{1.3}$ and tree age. The analysis included 1300 trees most of them at an age of 40 to 120 years. Equation 2:

$$
\mathrm{d}_{\mathrm{c}}=0.20+0.209 \mathrm{x} \mathrm{d}_{1.3}-0.015 \times \mathrm{a}
$$

where $\mathrm{dc}=$ crown diameter, $\mathrm{d}_{1.3}=$ diameter at $1.3 \mathrm{~m}$ and $\mathrm{a}=$ age.

The coefficient of multiple determination

$$
\mathrm{R}_{2}=0.77 ; \chi^{2}=10.3 ; \mathrm{p}\left(\chi^{2}=10.3\right)=0.59
$$

Equation 2 describes the strong relation between crown size and stem diameter. It, as well, shows that older trees have a smaller crown than younger trees, given the same stem diameter.

\section{Discussion and conclusion}

\section{Controlling pruning}

Early pruning leads to a thin branchy core in the stem and a large outside part of branch free wood. Therefore, early competition with neighbouring trees accelerates pruning and improves wood quality. The phase of pruning in the pole sized stage is especially important, because in this phase, the branches already tend to grow longer and larger in diameter. In addition, the production of branch free timber can be promoted through selection of monocormic trees with horizontally growing branches and no acute angle branches and forks (Storch 2011). In the early pole stage, thinning should be applied only when low quality trees have a strong negative impact on the vitality of potential future crop trees and in homogeneous stands where no self-differentiation occurs resulting in excessive competition.

In case that not enough competition exists, artificial pruning can be applied as well (Figure 2).

The optimal height of the crown base is a controversial topic that is discussed in the literature. This height depends on the production time and the diameter desired. 
Table 1 shows the required height of the crown base for an average annual radial increment of $1.5 \mathrm{~mm}$ and of $2.0 \mathrm{~mm}$. The indicated \%-values are the result of measurements of the 1,300 tree heights and of heights of the crown base (lowest living primary branch). Site conditions had no significant impact on these $\%$-values.

The absolute length of the branch free bole depends on the desired radial increment and on the site productivity, which is closely related to the height growth. On sites with low productivity this length has to be shorter.

Some authors (e.g., Diwold \& Hochbichler 2009) recommend a crown base at $30 \%$ tree height and a crown length of $70 \%$. Such a long crown would accelerate the annual radial increment and shorten the rotation period. However, it would as well reduce the potential number of crop trees per ha and the length of the branch free stem. Moreover, such a low crown base would increase the risk that large diameter branches at the crown base may die due to competition with neighbouring trees before the wanted stem diameter is reached. This die back of old branches should be avoided by continuous release, otherwise fungi may enter the stem, continue to grow in the stem through the large dead branches and finally lead to stem rot. Due to the increasing loss of value, the tree would need to be harvested before reaching the desired diameter.

Table 1 Annual radial increment and height of the crown base.

\begin{tabular}{|c|c|c|}
\hline annual radial increment $\left(\mathrm{ir}_{1,3}\right)$ & $1.5 \mathrm{~mm}$ & $2.0 \mathrm{~mm}$ \\
\hline $\begin{array}{l}\text { height of the crown base in } \% \\
\text { of the tree height at the time of } \\
\text { harvest }\end{array}$ & $60 \%$ & $50 \%$ \\
\hline
\end{tabular}

height of the lowest still visible dead branch in $\%$ of the tree height at the time of $\quad 50 \% \quad 40 \%$ harvest

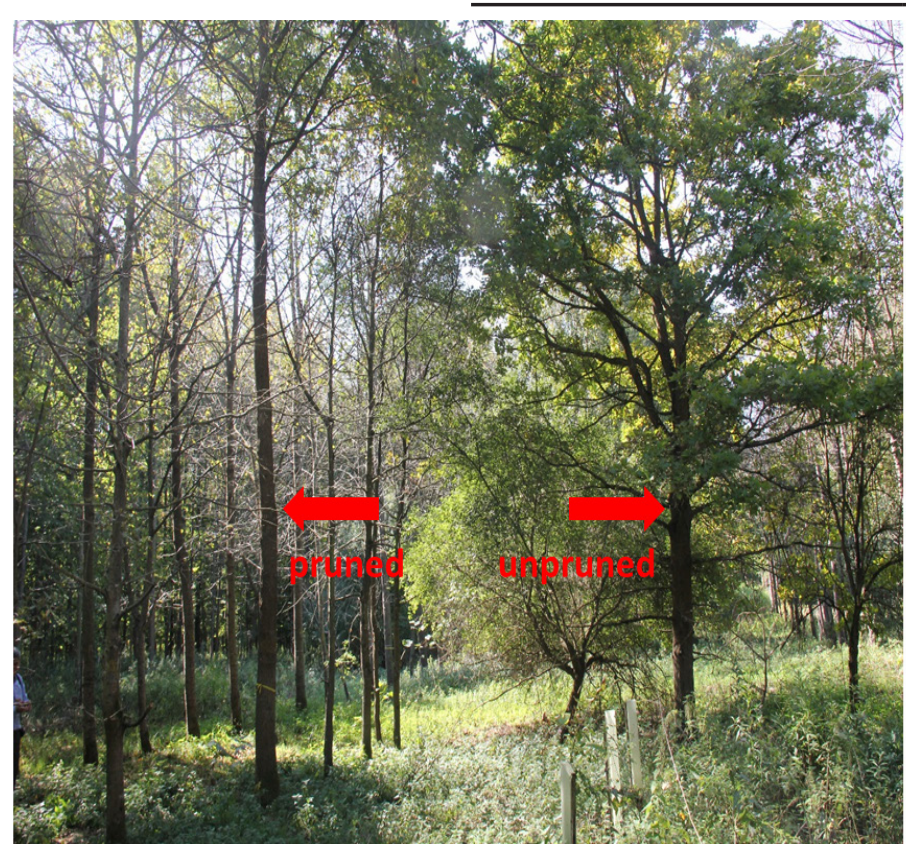

Figure 2 Improving quality through artificial pruning: the two widely spaced pedunculate oaks have been planted at the same time; the artificially pruned oak (left) shows a long clear stem, while the unpruned oak (right) produces long and large diameter branches. 


\section{Controlling diameter growth}

As described above, early competition accelerates natural pruning, but as well reduces diameter growth. The diameter growth of oak is heavily controlled by growing space. Figure 3 shows the strong effect of thinning on the annual radial increment of oak.

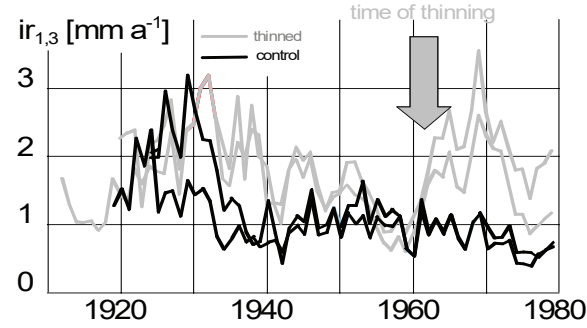

Figure 3 Annual radial increment ( $\mathrm{ir}_{1,3}$ ) of two oaks before and after release from competing beech at an age of 40 years (grey lines) compared to two oaks, which have not been released (black lines). The maximum additional increment after thinning is reached in years, when the growing conditions were favourable for the unreleased control as well.

Annual radial increment varies widely, depending on changing climatic conditions. The importance of even ring width for wood quality is often overestimated (Schulz 1959, Metzger 1999), especially as high annual variation is quite normal.

As there is a close relation between crown expansion and diameter growth, the required distance between trees can be calculated. To calculate average distance (D) between trees of the same size, the following simple distance rule can be applied.

Equation 3:

$$
\mathrm{D}=\mathrm{d}_{1,3} \times 20
$$

where $\mathrm{D}=$ distance between trees of similar dimension; $\mathrm{d}_{1.3}=$ diameter at $1.3 \mathrm{~m}$.

The simple model is describing the empirical findings for an average annual radial increment of $2 \mathrm{~mm}$ and a crown cover of $70 \%$ (derived from equation 2). Equation 3 applies for trees at all development stages. So, the distance between trees whose diameters are $15 \mathrm{~cm}$ is 3 $\mathrm{m}$ and $6 \mathrm{~m}$ between $30 \mathrm{~cm}$ diameter trees.

\section{Selection of future crop trees and the two-phase oak management system}

The three most important management activities for improving the quality of valuable oaks are (1) selecting the most promising trees as future crop trees, (2) promoting natural pruning and (3) controlling diameter growth through spacing and thinning. To increase overall value production, growth should be concentrated on those trees which show the best quality, the "future crop trees" or "target trees" (Weaver \& Spiecker 1993, Nicolescu 2001). Future crop trees are selected when their quality and vitality can be predicted with high probability. This is generally the case when about $50 \%$ of the final height has been reached. This is the height of the crown base of a mature tree with an average annual radial increment of $2 \mathrm{~mm}$ (Table 1).

Oak management is suggested to be split into two phases because of the specific dynamic of height - and basal area growth of trees. In the first phase, pruning is emphasized while in the second phase, in which the basal area increment of the individual tree is rapidly increasing, the diameter growth of the current branch free bole is promoted. Then at the beginning of the second phase, future crop trees are selected.

The strong relation between horizontal crown expansion and stem diameter is minimally influenced by site conditions. In even-aged stands, an almost linear relation between crown expansion and stem diameter exists (Figure 1). At young ages, oaks should be cautiously thinned to stimulate natural pruning, while later heavier release of well qualified future crop trees stimulates radial 
growth. This leads to a smaller knotty core.

To control the diameter growth of the future crop trees and for calculating the distance between the crop trees, equation 3 can be applied. For this calculation, a target diameter has to be defined. For a target $d_{1.3}$ of $60 \mathrm{~cm}$ the average distance between future crop trees should be $12 \mathrm{~m}$ and for $\mathrm{d}_{1.3}$ of $80 \mathrm{~cm} 16 \mathrm{~m}$. For selecting only, the best quality oaks as crop trees, the equal distribution criteria can be relaxed. A reduction of the distance to one neighbour crop tree can be compensated by a wider distance to the neighbour crop tree on the other side of the tree. This means that two or three valuable trees can grow together in a group. A major negative impact on vitality, quality, and growth per ha is not to be expected because trees with eccentric crowns show the same productivity per crown projection area as trees with concentric crowns (Spiecker 1991).

Table 2 Number of competitors to be cut in the following decade: the grey boxes indicate the number of competitors to be cut when the radial annual increment is $2.0 \mathrm{~mm}$.

\begin{tabular}{c|ccccccccc}
\hline age (yrs) & 40 & 50 & 60 & 70 & 80 & 90 & 100 & 110 & 120 \\
\hline $\mathrm{d}_{1,3}$ & & & & & & & & & \\
\hline 16 & 5.2 & 4.2 & 3.6 & - & - & - & - & - & - \\
20 & 4.5 & 3.9 & 3.5 & 3.1 & - & - & - & - & - \\
24 & 3.0 & 2.6 & 2.3 & 2.2 & 2.1 & 2.0 & - & - & - \\
28 & 2.2 & 1.8 & 1.6 & 1.5 & 1.4 & 1.3 & 1.3 & 1.3 & - \\
32 & - & 1.4 & 1.2 & 1.1 & 1.0 & 0.9 & 0.9 & 0.9 & 0.9 \\
36 & - & 1.1 & 0.9 & 0.8 & 0.8 & 0.7 & 0.7 & 0.7 & 0.6 \\
40 & - & - & 0.7 & 0.6 & 0.6 & 0.6 & 0.5 & 0.5 & 0.5 \\
44 & - & - & - & 0.5 & 0.5 & 0.4 & 0.4 & 0.4 & 0.4 \\
48 & - & - & - & - & 0.4 & 0.4 & 0.3 & 0.3 & 0.3 \\
\hline
\end{tabular}

The following assumptions are made: - constant diameter growth of 80 crop trees per ha; $-\mathrm{d}_{1,3}$ of the competitors to be thinned $=80 \%$ of the $\mathrm{d}_{1,3}$ of the future crop tree;

- crown cover $=70 \%$;

- every competitor is counted only once even if the release serves more than one crop tree.

The number of competitors to be cut per crop tree in a given time period decreases with age. Table 2 shows that this number depends on the diameter of the trees and the age of the trees. Figure 4 indicates that the number of competitors to be cut decreases when the size of the trees increases. In the early stage of thinning more competitors need to be cut than in the later stage. For example, at 40 years, five time as many competitors need to be cut than at age 80 within a given time interval. This can be explained by the fact that the cut of relatively young competitors with small crowns give only little additional space to the remaining trees. In addition, the removal of competitors at the early stage only favours one future crop tree while at later stages removing one competitor two or more crop trees may be favoured.

The tendency to produce epicormic branches can be already identified when the trees are young; as the proventive buds of the epicormic branches of oak always are connected to the pith (Figure 5), and the number of proventive buds in the lower part of the trunk is correlated with the number of these buds in the higher parts of the trunk of the same tree (Spiecker 1991). Therefore, through the observations in the lower part, the future development in the upper part can be predicted. 
However, even best practice can produce only a rather small percentage of valuable timber, as only a small number of future crop trees produce the valuable timber consisting of large diameter, branch free logs (Figure 6). If the 80 future crop trees per ha are released so that the average annual radial increment is $2 \mathrm{~mm}$ the contribution of the future crop trees to the total volume increment per ha from age 40 to 120 years is about $30 \%$; when this increment is $1.5 \mathrm{~mm}$ their contribution is only about $15 \%$ of the total stand volume increment.

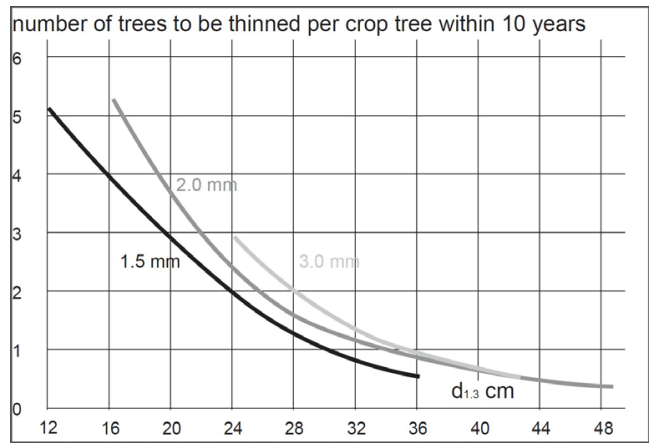

Figure 4 Number of trees to be thinned per future crop tree within a period of 10 years, when a certain diameter $\left(\mathrm{d}_{1.3}\right)$ has been reached, for trees growing at different speed (1.5, 2.0 and $3.0 \mathrm{~mm}$ annual radial increment). The calculation is based on equation 2 . It is assumed that 80 crop trees per ha have been selected, the crown cover is $70 \%$ and the diameter of the thinned trees is about $80 \%$ of the diameter of the future crop tree.
Even though the percentage of valuable timber of the total wood production is low, it can contribute to the economic success of the forest enterprise substantially. In the forest district of Johanniskreuz, Germany, for example, the average price of assortments including all tree species in 2012 was $67 € / \mathrm{m}^{3}$ while the average price of all oak assortments on average was $180 € / \mathrm{m}^{3}$. The proportion of valuable oak accounted for only one percent of the total volume cut within the enterprise but contributed ten percent to the income (Steckel, personal communication 2018).

There are many reasons for growing oaks. Oaks are desired by people. They grow on many sites and produce valuable timber.

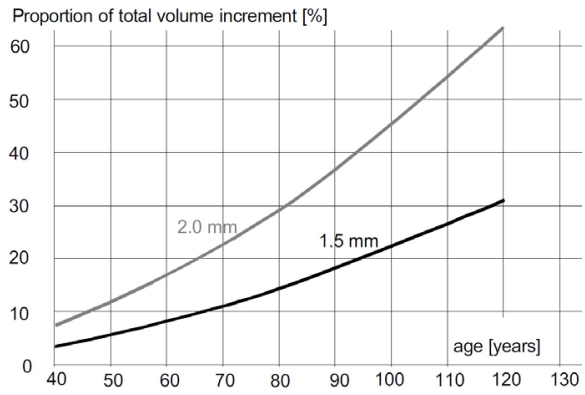

Figure 6 Contribution of 80 future crop trees per ha to the total volume increment of an oak stand over time with a current annual radial increment $\left(\mathrm{ir}_{1,3}\right)$ of 1.5 or 2.0 $\mathrm{mm}$ respectively (calculation based on equation 2).

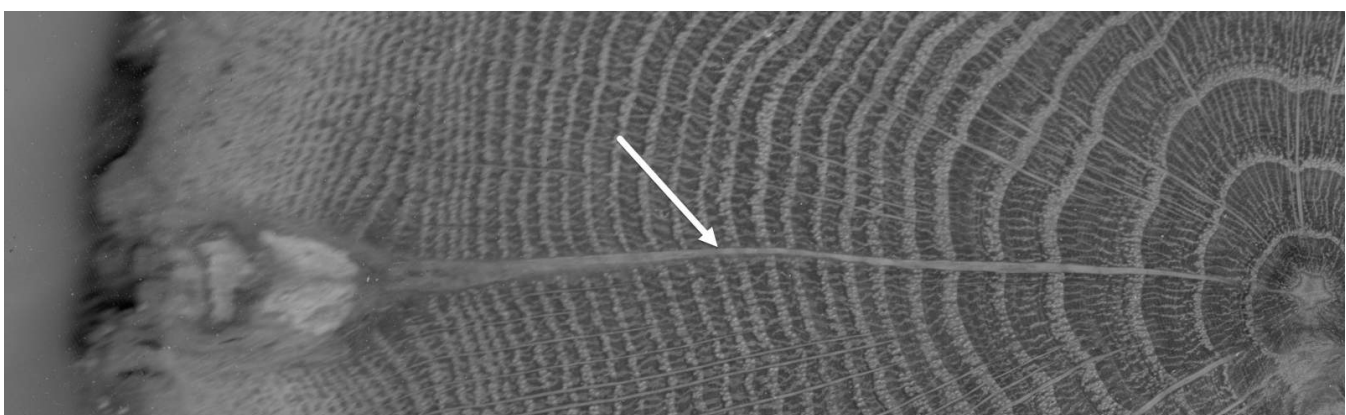

Figure 5 Surface of a stem disc: The proventive buds which produce epicormic branches are always connected to the pith (see arrow). 
Economic success is driven by the amount of valuable wood. Through silvicultural methods, the best qualified future crop trees can be selected and the natural pruning as well as the diameter growth can be controlled and promoted by silvicultural practices. By distinguishing two treatment phases: phase 1 (promoting pruning) and phase 2 (promoting diameter growth) managing for valuable oak wood production can be optimized. In phase 2 the volume growth is concentrated on the future crop trees. Repeating thinning stimulates diameter growth and thus avoids the slowdown of annual radial increment under natural conditions. The end result is that a branch free stem of large diameter can be realized.

\section{References}

Attocchi G., Skovsgaard J.P., 2015. Crown radius of pedunculate oak (Quercus robur L.) depending on stem size, stand density and site productivity. Scandinavian Journal of Forest Research, 30(4): 289-303. https://doi. org/10.1080/02827581.2014.1001782.

Bary Lenger A., Nebout J.P., 1993. Les chênes pédonculé et sessile en France et en Belgique: écologie, économie, histoire, sylviculture. Editions du Perron, Alleur-Liège, 604 pp.

DiwoldG.,HochbichlerE., 2009.Eichenwertholzerziehung, Anleitung zur Eichenbewirtschaftung im Nördlichen Alpenvorland Landwirtschaftskammer Oberösterreich, Linz, 16 pp.

Eaton E.G.S.D.J., Caudullo G., Oliveira S., de Rigo D., 2016. Quercus robur and Quercus petraea in Europe: distribution, habitat, usage and threats. In: San-MiguelAyanz J., de Rigo D., Caudullo G., Houston Durrant T., Mauri A. (Eds.), European atlas of forest tree species. Publ. Off. EU, Luxembourg, 160-163.

Evans J., 1984. Silviculture of broadleaved woodland. Forestry Commission Bulletin, 62: 1-32.

FAO, 2006. Global Forest Resources Assessment 2005; Progress towards sustainable forest management. Rome, 320 pp.

Jahn G., 1991. Temperate deciduous forests. Ecosystems of the World 7, 377-502.

Lavnyy V., Spiecker H., 2016. Eichenwälder in der Ukraine und in Deutschland. AFZ-DerWald, 41-45.
Maleki K., Zeller L., Pretzsch H., 2020. Oak often needs to be promoted in mixed beech-oak stands -the structural processes behind competition and silvicultural management in mixed stands of European beech and sessile oak. iForest - Biogeosciences and Forestry 13(1): 80-88. https://doi.org/10.3832/ifor3172-013.

Metzger M., 1999. Qualitätseigenschaften des Holzes von Traubeneichen aus drei süddeutschen Beständen in Abhängigkeit von der Jahrringbreite. Schriftreihe Agrarwissenschafliche Forschungser-gebnisse, Bd. 16. Verlag Dr Kovac, Hamburg, 193 pp.

Nicolescu V.-N., 2001. The concept of crop (elite) trees and its use in the management of stands designated to the production of high-value timber. Bulletin of the Transilvania University of Braşov, 8: 141-14.

Opera A.M., Borlea G.F., Dronca D., 2018. Oak species - providing renewable and sustainable raw materials, enrich the ecosystem services and fulfilling the social demands. Case-study - Western Romania. Scientific Papers. Series E. Land Reclamation, Earth Observation \& Surveying, Environmental Engineering, VII: 225233.

Schulz H., 1959. Untersuchungen über Bewertung und Gütermerkmale des Eichenholzes aus verschiedenen Wuchsgebieten. Schriftreihe der Forstlichen Fakultät der Universität Göttingen und Mitteilung der Niedersächsischen Forstlichen Versuchsanstalt. Bd. 23. J.D. Sauerländer's Verlag. Frankfurt am Main, 88 pp.

Spiecker H., 1991. Zur Steuerung des Dickenwachstums und der Astreinigung von Trauben- und Stieleichen (Quercus petraea (Matt.) Liebl. und Quercus robur L.). Schriftenreihe der Landesforstverwaltung Baden-Württemberg, Bd. 72, 150 pp. English version: http://www.freidok.uni-freiburg. de/volltexte/6533/

Storch J.K., 2011. Astentwicklung und Astreinigung in Abhängigkeit vom Dickenwachstum bei Buche (Fagus sylvatica L.) und Eiche (Quercus petraea (Matt.) Liebl.; Quercus robur L.). Dissertation zur Erlangung der Doktorwürde der Fakultät für Forst - und Umweltwissenschaften der Albert - Ludwigs Universität Freiburg i. Brsg., 285 pp.

Timbal J., Aussenac G., 1996. An overview of ecological and silviculture of indigenous oaks in France. Ann. Sci. For., 53: 649-661. https://doi.org/10.1051/ forest: 19960243

Weaver G., Spiecker H., 1993. Silviculture of highquality oaks: questions and future research needs. Ann. Sci. For., 50(6): 531-534. https://doi.org/10.1051/ forest: 19930601 